\title{
Confirmatory Factors Analysis Practice Level and Guidelines for Developing Teachers' Performance Standards and Conduct Standards
}

\author{
Songsak Phusee-orn ${ }^{1}$ \\ ${ }^{1}$ Faculty of Education, Mahasarakham University, Mahasarakham, Thailand \\ Correspondence: Songsak Phusee-orn, Faculty of Education, Mahasarakham University, Mahasarakham, \\ Thailand. Tel: 87-872-7151. E-mail: songsak.p@msu.ac.th
}

Received: June 5, $2021 \quad$ Accepted: July 8, $2021 \quad$ Online Published: July 20, 2021

doi:10.5539/hes.v11n3p169 URL: https://doi.org/10.5539/hes.v11n3p169

\begin{abstract}
The objectives of this research are 1) to analyze the confirmatory factors performance standards and conduct standards of teachers who have been certified through the Teachers' Council of Professional Knowledge Standards training 2) to study the level of compliance with performance standards and conduct standards, and 3) to study the development guidelines according to performance standards and conduct standards. The samples consisted of 348 persons who passed the teachers' professional knowledge training standard of the Teachers Council of Thailand by Multi-Stage Random Sampling. The instruments used to collect data are: quality-validated questionnaires from experts and try out before use. Analyze data with Second-Order Confirmatory Factor Analysis, S.D., and Content Analysis. The results of the research were as follows: 1) The second-order confirmatory factors analysis on performance standards showed that the model was consistent with the empirical data. It shows that the performance standard consisted of 12 factors. In terms of conduct standards, it found that the model was consistent with the empirical data additionally. It showed that the standard of conduct consisted of 5 factors. 2) Compliance with overall performance standards is at a high level and conduct standards are at a very high level. 3) There are seven development guidelines according to performance standards and six guidelines for development according to the conduct standards which the experts have approved.
\end{abstract}

Keywords: Confirmatory Factor Analysis, performance standards, conduct standards

\section{Introduction}

Teacher, Professional Teacher, and Teacher profession; is an honorable job and is a job that creates quality people for society. Teachers have a duty or career in teaching learners to thrive in the principles, thinking, reading, and self-practice, and guidelines for living with the social order. And most importantly, teachers are the most significant factor in determining student achievement (Gallagher, 2002). At present, persons who wish to work in the teaching profession must also receive a teaching license, and there is a "Teachers Council of Thailand" as the institute to operate in this regard.

The "Teachers Council of Thailand" which serves as the Teachers and Educational Personnel Council, was established under the Teachers and Educational Personnel Council Act 2003; plays a role in setting professional standards, issuing and revoking professional licenses, supervising compliance with professional standards, and professional ethics. Including educational professional development, which elevates the instructive profession to a higher level. One significant part is a teaching profession license, meaning a certificate issued to a teacher who is a primary practitioner in teaching and promoting apprentices' learning through various means. In early childhood, rudimentary and tertiary education establishments with a lower degree, both public and private. There are several methods for obtaining a teaching profession certificate, all of which are expected to be a means of screening those who will continue to pursue qualified and proficient teachers in the future because teacher quality is the most important factor affecting student outcome (OECD, 2005; Barber \& Mourshed, 2007). The method is Certification of knowledge from the teachers' professional knowledge standard training of the Teachers Council of Thailand by assigning higher education institutions to be the Teachers Council of Thailand: Development institution of Faculty of Education, Mahasarakham University. There is one of the development departments in this way. To study the composition of the standard of work and what the standard of conduct looks comparable. Is it compliant? Including the educational level of compliance with the standards? How much practice was being performed? There would be a piece of essential information to reflect the results of the 
development of such teachers. Finally, there is also a study of guidelines for promoting development following performance standards and conduct standards too. There will be important information for the relevant departments to design and plan for long-term improvement.

\section{Method}

In conducting this research, the researcher has performed in 2 phases as follows:

\subsection{Phase I}

Confirmatory Factor Analysis and analysis of the level of compliance with performance standards and conduct standards. The population is those who have received knowledge from the Teachers Council of Thailand: Development institution of Faculty of Education, Mahasarakham University at least one standard and performs 908 teaching duties in educational institutions. The samples are the person who passed the teachers' professional knowledge training standard of the Teachers Council of Thailand: Development institution of Faculty of Education, Mahasarakham University, and performed teaching duties in educational institutes of 348 people. There are determine the sample size using Krejcie and Morgan table and performing Multi-Stage Random Sampling. The data collection of the teachers in the sample group was self-assessed, and the school administrator who was affiliated provide the information to support the performance of the sample group.The researcher used a questionnaire examined by experts to tryout 23 participants with the Teachers Council of Thailand: Development institution of Faculty of Education, Mahasarakham University. Analyze the discrimination power by the Item Total Correlation method and finding the reliability value using Cronbach's alpha Coefficient method, the results of the quality analysis were as follows. 1) There were 12 standards for performance, 36 questions in total, and showed that they had a discrimination power ranging from .316 to .823 (all statistically significant) with a total reliability value of .948. 2) Conduct standards (Professional Ethics) There are five standards, 13 questions in total, found that they have discrimination power from .199 to .824 (all statistically significant) with reliability in the complete version .893 .The researcher collects the data by examining preliminary data from the Academic Service Center and disseminating educational innovation Faculty of Education Mahasarakham University; is the training institution and coordinated calls to send questionnaires to the sample group to answer and return by post. Data were analyzed by Chi-square, Goodness of Fit Index (GFI) Root Mean Square Error of Approximation (RMSEA).

\subsection{Phase II}

Study of development guidelines according to performance standards and conduct standards. Samples in providing information on development guidelines for performance standards and conduct standards are divided into three groups. 1) Persons certified by the Teachers Council of Thailand: Development institution of Faculty of Education, Mahasarakham University, and taught in educational institutions of 348 people in the same group as the first phase but provided information on the part of the development guideline, which is an open-ended question. 2) School administrators who have been certified by the Teachers Council of Thailand: Development institution of Faculty of Education, Mahasarakham University, performing teaching duties of 348 people in the same group as Phase 1, but provide information on the part of the development guideline, which is an open-ended question. 3) Three experts consider the appropriateness of the development guidelines according to their performance standards and conduct standards. The research tools used in this phase were questionnaires (Phase 1), considering only open-ended questions about the development guideline and the feasibility assessment form of the recommendation developed by experts. The data in this section is qualitative data using content analysis for data analysis in this phase.

\section{Results}

The researcher has divided the analysis of the data into three parts according to the objectives as follows:

\subsection{Confirmatory Factor Analysis Results}

This section divided into two parts: confirmation of factor analysis on performance standards and approval of conduct standards. The analysis results are as follows: 
3.1.1 The Results of the Second Confirmation Factor Analysis on the Performance Standard Showed in Figure 1.

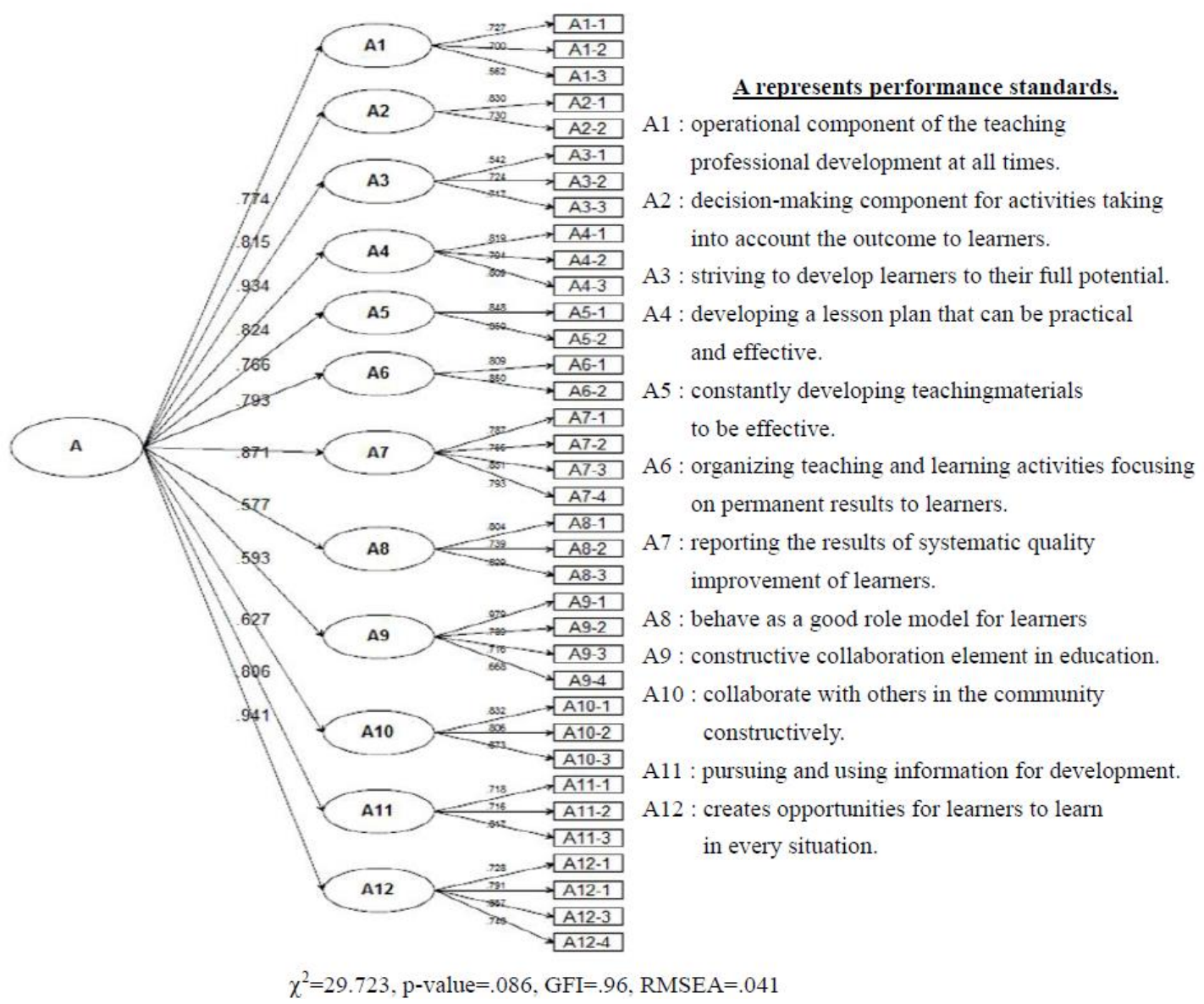

Figure 1. Results of the second confirmatory factor analysis in terms of performance standards

The results of the second-order confirmatory factors analysis in performance standards consistent with the empirical data. $\left(\chi^{2}=29.723\right.$, p-value=.086, GFI=.96, RMSEA=.041) The study showed that the operating standards consisted of 12 factors, in descending order of factor loading as follows: Creates opportunities for learners to learn in every situation (A12), Commitment to developing learners to their full potential (A13), Reporting the results of systematic quality improvement of learners ( A7), Developing a lesson plan that can be practical and effective (A4), A decision-making component for activities taking into account the outcome to learners (A2), Pursuing and using information for development (A11), Organizing teaching and learning activities focusing on permanent results to learners (A6), The operational component of the teaching professional development at all times (A1), Constantly developing teaching materials to be effective (A5), Collaborate with others in the community constructively. (A10), the constructive collaboration element in education (A9), and Behave as a good role model for learners (A8), respectively. 
3.1.2 The Results of the Second-order Confirmatory Factor Analysis on the Conduct Standard are Shown in Figure 2

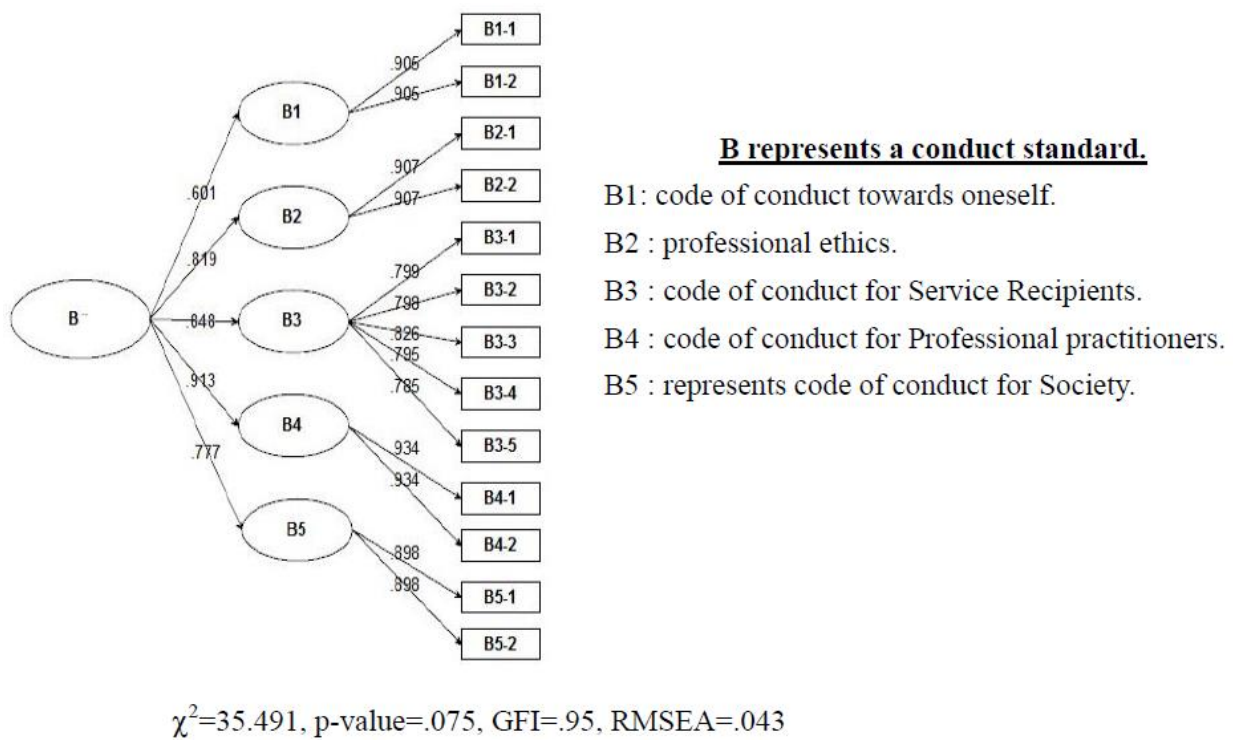

Figure 2. The results of the second-order confirmatory factor analysis in terms of conduct standard

The results of the second-order confirmatory factor analysis on the conduct standard consistent with the empirical data. $\left(\chi^{2}=35.491, \mathrm{p}\right.$-value $=.075, \mathrm{GFI}=.95$, RMSEA=.043 $)$ The study showed that the standard of conduct consisted of 5 factors, in descending order of factor loading as follows: Code of Conduct for Professional component (B4), Professional Ethics component (B2), Code of Conduct for Society (B5), Code of Conduct for Service Recipients (B3) and Code of conduct towards oneself (B1), respectively.

3.2 The Results on the Level of Compliance with Performance Standards and Conduct Standards Present in Tables 1 and 2

Table 1. Shows the mean and standard deviation for compliance with performance standards

\begin{tabular}{llrrl}
\hline No. & Factors & M & S.D. & Level \\
\hline A1 & $\begin{array}{l}\text { Operational component of the teaching professional } \\
\text { development at all times }\end{array}$ & 4.21 & .602 & Very high \\
A2 & $\begin{array}{l}\text { Decision-making component for activities taking into } \\
\text { account the outcome to learners }\end{array}$ & 4.65 & .456 & Very high \\
A3 & Striving to develop learners to their full potential & 4.46 & .464 & High \\
A4 & Developing a lesson plan that can be practical and effective & 4.30 & .573 & High \\
A5 & Constantly developing teaching materials to be effective & 4.25 & .597 & High \\
A6 & Organizing teaching and learning activities focusing on & 4.47 & .547 & High \\
& permanent results to learners & & & \\
A7 & Reporting the results of systematic quality improvement of learners & 4.27 & .547 & High \\
A8 & Behave as a good role model for learners & 4.76 & .397 & Very high \\
A9 & Constructive collaboration element in Education & 4.75 & .378 & Very high \\
A10 & Collaborate with others in the community constructively & 4.68 & .461 & Very high \\
A11 & Pursuing and using information for Development & 4.37 & .499 & High \\
A12 & Creates opportunities for learners to learn in every situation & 4.38 & .508 & High \\
\hline Total & & 4.47 & .368 & High \\
\hline
\end{tabular}

Table 1 shows that overall performance standards were observed at a high level. When considering each factor, the top three factors with the highest operating average are: Behave as a good role model for learners (A8), factors of Constructive collaboration element in education (A9), and factors of Collaborate with others in the community constructively (A10), respectively. The factors with the lowest average of performance were the factors of practice, and the operational component of the teaching professional development at all times (A1). 
Table 2. Shows the mean and standard deviation for compliance with the conduct standards

\begin{tabular}{lllll}
\hline No. & Factors & M & S.D. & Level \\
\hline B1 & Code of conduct towards oneself & 4.73 & .438 & Very high \\
B2 & Professional ethics & 4.81 & .365 & Very high \\
B3 & Code of Conduct for Service Recipients & 4.79 & .331 & Very high \\
B4 & Code of Conduct for Professional Practitioners & 4.76 & .418 & Very high \\
B5 & Code of Conduct for Society & 4.74 & .415 & Very high \\
\hline Total & 4.77 & .320 & Very high \\
\hline
\end{tabular}

Table 2 showed the overall and individual components had the highest levels of compliance with the conduct standards. The factor with the highest average level of conduct was professional ethics (B2), while the factor with the lowest average level of conduct was the code of conduct towards oneself (B1).

\subsection{The Results of the Study of the Development Guidelines}

The results of the study of the development guidelines according to the performance standards and the conduct standards are detailed as follows: 3.1) Guidelines for developing performance standards are as follows: 1) Executives/agencies should promote new knowledge seeking. It is always encouraging a higher level of further education with taking in various projects to apply knowledge and experience to the development of learners effectively. 2) Executives/affiliations should promote classroom action research leading to systematic learner development. 3) The administrators/agencies should promote a learning management plan improvement because it is suitable for learners and can use with quality. Moreover, it includes organizing teaching activities based on the apprentices' focus and applying new guidelines relevant to the context. 4) The administrators/agencies should encourage participation in academic activities organized by the organization, institution, or association and have the ability to choose activities with love and good hope for learners. 5) The administrators/agencies should promote the determination to develop learners to their full potential. It makes the best efforts of teachers to make the learners as much as possible according to their aptitudes, interests, and needs. Analyzing and diagnosing the factual requirements of the pupils modify the teaching method to be more effective. It includes promoting the development of various areas according to the potential of each learner systematically. 6) Promote the use of new technology and adapt it to suit the management of learning and being a person of education. 7) Encourage the school to have a systematic and continuous monitoring system so that the teaching and learning management will be of high quality and full potential. 3.2) Guidelines for development according to the standard of conduct are as follows: 1) Administrators/original affiliation should provide activities that encourage teachers to love and faith in their profession, love of teaching, selflessness, and endure hard work. 2) Executives/original affiliation should organize activities that promote behavior to be a virtuous example for students. 3) Executives/original affiliation should promote and emphasize the practice of discipline, punctuality, sacrifice, public consciousness, unity, and cooperation among the faculty. 4) Executives/original affiliation should foster honesty and responsibility for their work. 5) Executives/original affiliation should promote helping, compassion, and encouraging students. 6) Executives/original affiliation should promote cooperation in various operations with willingness and sincerity to their colleagues.

\section{Discussion}

1. From the research findings in the analysis of the second-order confirmatory factor analysis in performance standards, found that the model is consistent with the empirical data show that in working to become a professional teacher should have to create opportunities for learners to learn and develop to their full potential, reporting systematic improvements in apprentices' quality, developing teaching plans that can be effective, deciding on various activities with due regard to the results to learners, seek and use the information to develop, organize teaching and learning activities with an emphasis on permanent results for students, always carry out academic activities related to professional development, develop media for instruction to be effective always, collaboratively with others in the community and school. and behave as a role model for students which is considered important because teacher quality is the most important factor affecting the student outcome (OECD 2005; Barber \& Mourshed 2007). Therefore, various characteristics of teachers affect the teaching efficiency which is consistent with the research of Kim LE, Jörg V, Klassen RM (2019) that found openness, conscientiousness, extraversion, and emotional stability of teachers were positively associated with teacher effectiveness, especially for evaluations of teaching. Teacher emotional stability, extraversion, and conscientiousness were negatively associated with burnout. Other than that, to make teaching effective, teachers must encourage students to participate which is consistent with the findings of Kaendler, Celia \& Wiedmann, 
Michael \& Rummel, Nikol \& Spada, Hans. (2014) that found teachers can foster student interaction in collaborative learning settings. The teacher has to have five competencies include the ability to plan student interaction, monitor, support, and consolidate this interaction, and finally reflect upon it. In addition to relying on cooperation with students, it also requires communication and collaboration of colleagues that will have a positive effect on teaching efficiency and make it an innovative teacher, according to the results of the study by Pantic and Wubbels (2010) found that innovative teacher needs to have the ability to communicate with students from different backgrounds and cooperate with other colleagues, and supported by the study found that communication skills are important for innovative teaching (Koster et al. 2005).

From the results of the second-order confirmatory factor analysis of the standard of conduct, the model is consistent with the empirical data and showed that the standard of conduct consists of 5 components in order of the weight of the factor loading in descending order as follows: ethics to colleagues, professional ethics, ethics to society, ethics for clients and the code of conduct towards oneself, respectively. This is regarded as an important standard because the teaching profession, in addition to performing well, must also be good role models in various behaviors to create good people. This is the concern with SEAME INNOTECH (2014), which defines the scope and competency standard of teachers in the 21st century of Southeast Asian countries. In addition to having professional knowledge, professional skills, personality, professional development, and lifelong learning, ethics and professional values are also defined. Furthermore, the study of Saothong, Saisawart, and Den Chanetiyoung (2019), also found that the teacher competency development strategy to align with Thailand 4.0 learning management of basic education institutions consists of six strategies: knowledge skills, personality, social, teaching, and morality. And according to a study by Phinyo, Suttiporn, and others (2016), found that in addition to achieving good service achievements, teamwork, morality, and ethics are also available.

2. From the conclusion of the study about the level of practice with the standard of performance, it is found that the factor with the highest level of performance in the top three is good role models for learners, creative collaboration with other institutions. and collaborating with others in the community creatively, respectively, in which the teacher's work needs to be a good model to create faith from learners, especially in the context of Thailand, teachers must work with communities or other organizations. To integrate work to improve the quality of education which may come to help in various processes, especially less experienced teachers, it is important to have a coach to give advice. This is consistent with the study found that the influence instructional coaches have on individual teachers, students in classes where teachers are coached and there is a positive relationship between coaching and teacher competency (Frazier, R.A. 2018).

From the conclusion of the research, found the mean of the lowest level of operation was the practice of academic activities on teacher professional development always shows that the teacher still lacks planning for self-development to be professional. There is considered important because it will increase knowledge and various experiences as well. However, the problem may be because the budget for teacher development still lacks clear plans. Most often it is a short-term project. Causing uneven development this also includes problems in evaluating teachers' performance as well, according to the results of the study by Pimpa, Nattavud and others (2005) found that problems of the current teacher performance appraisal can be identified to three major types: Problems from the mismanagement of the system, problems arising from the evaluators, and problems from the applicants. The major causes of the problem are the lack of long-term planning of the performance appraisal and the frustration from the education reform process.

3. According to the results of the study, the approaches for development in accordance with performance standards include encouraging the pursuit of new knowledge, continue studying at the higher level, and join in various development projects. This is considered important because students have a high achievement effect from qualified teachers. The results correspond to the study of Santín, Daniel and Gabriela Sicilia (2017), which revealed that differences in teachers' efficiency across schools with significant effects on students' achievement. In addition, Heinz, Manuela (2013), also revealed that teaching experience is positively correlated with achievements in practical teaching. And the results are also consistent with the study of Watson (1992), Ross and Bruce (2007), which indicated that teacher efficacy beliefs are positively correlated with student achievement.

In addition, the conclusions of the study show that teachers should be encouraged to do the classroom action research, which is important because it is research to find out, to improve to become better results and to improve the quality of learners. If teachers have the skills of doing classroom action research, it will lead to systematic development. These results concern the study of Tomal (2010), which indicated that Action research is useful for teachers who use it for classroom improvement. According to the findings, the use of new technologies should be promoted to suit learning, which is important because current knowledge has no limits. Learners can pursue their own knowledge by using technology. Therefore, teachers should apply technology to 
their advantages. In line with Hillman (2012), it was found that in the 21st century, teachers must be universal and need to be able to apply technology to manage to learn. Furthermore, Phutkeaw, Vatin and Prasong Saihong. (2017), found that in addition to learning courses, designing learning management, another important aspect is the use and development of innovative media for communication. In addition, developing teachers to have confidence in using technology will have a positive impact on learners (Allinder, 1994), and will also affect students' attitudes, skills and preferences (Fusco, 2021) and final cause in a good culture (Dack and Tom Linson, 2015).

\section{Acknowledgments}

I would like to thank the Faculty of Education, Mahasarakham University to encourage and support this research. Thank you so much for the research samples and the experts who checked the quality of the tools. I would like to thank the students who helped in collecting the data. Finally, I would like to thank my colleagues for recommending the journal and manuscript preparation.

\section{References}

Allinder, R. M. (1994). The relationship between efficacy and the instructional practices of special education teachers and consultants. Teacher Education and Special Education, 17, 86-95. https://doi.org/10.1177/088840649401700203

Barber, M., \& Mourshed, M. (2007). How the world's best performing school systems come out ontop. McKinsey Report. Retrieved from http://www.mckinsey.com/App_Media/Reports/SSO/Worlds_School_Systems_Final.pdf

Dack, H., \& Tomlinson, C. A. (2015). Inviting all students to learn. Educational Leadership, 72(6), 10-15.

Frazier, E. (2018). The impact of instructional coaching on teacher competency, job satisfaction, and student growth. A dissertation submitted to the Graduate the University of Colorado.

Fusco, E. (2012). Effective questioning strategies in the classroom: A step-by-step approach to engaged thinking and learning $K-8$. New York, NY: Teachers College Press.

Gallagher, H. (2002). The relationship between measures of teacher quality and student achievement: The case of Vaughn elementary. New Orleans.

Heinz, M. (2013). Tomorrow's teachers-selecting the best: An exploration of the quality rationale behind academic and experiential selection criteria for initial teacher education programmes. Educational Assessment, Evaluation and Accounability, 25, 93-114. https://doi.org/10.1007/s11092-013-9162-1

Hillman, N. (2012). Learning 21st Century Skill: Implementation of Programs and Practices. Doctor of Education, Faculty of the USC Rossier School of Education University of Southern California.

Kaendler, C., Wiedmann, M., Rummel, N., \& Spada, H. (2014). Teacher Competencies for the Implementation of Collaborative Learning in the Classroom: a Framework and Research Review. Educational Psychology Review, 27. 1-32. https://doi.org/10.1007/s10648-014-9288-9

Kim, L. E., Jörg, V., \& Klassen, R. M. (2019). A Meta-Analysis of the Effects of Teacher Personality on Teacher Effectiveness and Burnout. Educ Psychol Rev., 31(1), 163-195. https://doi.org/10.1007/s10648-018-9458-2

Koster, B., Brekelmans, M., Korthagen, F., \& Wubbels, T. (2005). Quality requirements for teacher educators. Teaching and Teacher Education, 21(2), 157-176. https://doi.org/10.1016/j.tate.2004.12.004

OECD. (2005). Teachers matter: attracting, developing and retaining effective teachers. Paris: OECD.

Pantic, N., \& Wubbels, T. (2010). Teacher Competencies as a Basis for Teacher Education-Views of Serbian Teachers and Teacher Educators. Teaching and Teacher Education, 26, 694-703. https://doi.org/10.1016/j.tate.2009.10.005

Pimpa, N. (2005).Teacher Performance Appraisal in Thailand: Poison or Panacea?. Educ Res Policy Prac, 4, 115-127. https://doi.org/10.1007/s10671-005-1547-6

Phinyo, S. (2016). The Development of Strategies to Promotion for Teacher Competency of Municipality School. Journal of Humanities and Social Sciences University of Phayao, 4(1).

Phutkeaw, V., \& Prasong, S. (2017). A Guideline to Develop Teachers in Learning Management Effectiveness for Small Schools of Nong Khai Primary Education Service Area Office 1. Journal of Educational Administration and Supervisor, Mahasarakham University, 8(1).

Ross, J., \& Bruce, C. (2007). Professional development effects on teacher efficacy: Results of a randomized field 
trial. The Journal of Educational Research, 101, 50-59. https://doi.org/10.3200/JOER.101.1.50-60

Santín, D., \& Sicilia, G. (2017). Dealing with endogeneity in data envelopment analysis applications. Expert Syst Appl, 68, 173-184. https://doi.org/10.1016/j.eswa.2016.10.002

Saothong, S., \& Den, C. (2019). The strategy on teacher competency development in basic education schools according to education 4.0. Journal of MCU Nakhondhat, 6(9).

Seameo, I. (2014). Teaching competency standards in Southeast Asian Countries. Retrieved from http://www.seameo.org/SEAMEOWeb2/imagesstories/Publications/Centerspub/2012TeachingCompetencyS tandards/Teaching CompetencyStd.pdf

Tomal, D. R. (2010). Action research for educators (2nd ed). Rowman \& Littlefield Publishers.

Watson, S. (1992). A study of the effects of teacher efficacy on academic achievement of third-grade students in selected elementary schools in South Carolina. Doctoral dissertation, South Carolina State College, Orangebury, Proquest Dissertations and Theses (ATT9230552).

\section{Copyrights}

Copyright for this article is retained by the author(s), with first publication rights granted to the journal.

This is an open-access article distributed under the terms and conditions of the Creative Commons Attribution license (http://creativecommons.org/licenses/by/4.0/). 